\title{
Regulated Deficit Irrigation and Density of Erythroneura spp. (Hemiptera: Cicadellidae) on Grape
}

\author{
MICHAEL J. COSTELLO ${ }^{1}$ \\ Horticulture and Crop Science Department, California Polytechnic State University, San Luis Obispo, CA 93407
}

\begin{abstract}
J. Econ. Entomol. 101(4): 1287-1294 (2008)
ABSTRACT This study looked at regulated deficit irrigation (RDI) on leafhoppers in the genus Erythroneura (Erythroneura elegantula Osborn, or western grape leafhopper, and Erythroneura variabilis Beamer) (Hemiptera: Cicadellidae), which are serious pests of cultivated grape (Vitis vinifera L.) in California. RDI is an irrigation strategy that reduces irrigation during a critical point in the phenology of a cultivated perennial crop, to improve vegetative balance and crop quality. Erythroneura spp. are known to respond negatively to vine water stress, and the second generation of leafhoppers begins during a potential RDI initiation period, between berry set and veraison (beginning of fruit maturation). In experiments at commercial wine grape vineyards, I imposed deficits of between 25 and $50 \%$ of crop full evapotranspiration $\left(\mathrm{ET}_{\mathrm{c}}\right)$ between berry set and veraison, with control treatments based on the growers' standard irrigations (typically between 0.8 and $1.0 \mathrm{ET}_{\mathrm{c}}$ ), and then we counted leafhopper nymphs weekly, and leafhopper eggs after the second generation. Results show a consistent reduction of second generation nymphal density with this type of RDI, with average density $\approx 50 \%$ lower under deficit treatments in all three studies. Deficit irrigation reduced second generation egg density by $54 \%$ at one site and by $29.9 \%$ at another. These results confirm previous studies regarding the sensitivity of Erythroneura spp. to grapevine water stress, and, in addition, they show that a season-wide irrigation deficit is not necessary for reduction in leafhopper density. Results suggest that lower oviposition at least partly explains the lower nymphal density in the deficit treatments.
\end{abstract}

KEY WORDS leafhoppers, deficit irrigation, grape, vineyard, water

Leafhoppers in the genus Erythroneura (Erythroneura elegantula Osborn and Erythroneura variabilis Beamer) (Hemiptera: Cicadellidae: Typhlocybinae) are a major pest concern for California grape producers. Leafhoppers are the state's number one insect pest with respect to chemical treatment efforts: based on the use of the most common insecticides at the time of this study, $\approx 40 \%$ of the state's grape acreage is treated for these insects (California Department of Pesticide Regulation 2000). These leafhoppers puncture cells in the leaf mesophyll, extracting the contents. The loss of chlorophyll produces a white stippled appearance of the leaf, and high population density can reduce a vine's photosynthetic rate.

Some other Hemiptera that exploit their host plants in the same way are known to respond negatively to plant water stress. Connor (1988) found a preference by Corythucha arcuata (Say) (Hemiptera: Tingidae), a mesophyll feeder, on Quercus alba $\mathrm{L}$. leaves at -0.1 and -0.4 megapascals (MPa) compared with -0.8 and $-1.5 \mathrm{MPa}$, and Flint et al. (1996) noted lower densities of Lygus hesperus Knight (Hemiptera: Miridae) on cotton (Gossypium hirsutum L.) watered biweekly versus weekly. There is also some evidence that phloem-feeding leafhoppers respond in a similar manner.

\footnotetext{
${ }^{1}$ Corresponding author, e-mail: mcostell@calpoly.edu.
}

Hoffman et al. (1990) and Hoffman and Hogg (1992) found that Empoasca fabae (Harris) had longer developmental periods, higher egg mortality, and lower densities on water-stressed alfalfa, Medicago sativa $\mathrm{L}$.

Previous studies on Erythroneura spp. have indicated nymphal densities are lower with reduced irrigation typically indicated as a proportion of crop evapotranspiration $\left(\mathrm{ET}_{\mathrm{c}}\right)$, the estimated amount of water needed to replace the water transpired through the plant and evaporated from the soil surface. Trichilo et al. (1990) found that on vines ('Thompson Seedless' [aka 'Sultana']) irrigated season-wide at 0.8 $\mathrm{ET}_{\mathrm{c}}$ or $0.4 \mathrm{ET}_{\mathrm{c}}$ compared with $1.2 \mathrm{ET}_{\mathrm{c}}$, density of $E$. elegantula and E. variabilis was significantly lower at one site in the San Joaquin Valley (Westside Field Station) but not another (Kearney Agricultural Center $[\mathrm{KAC}]$ on the east side of the valley). However, Daane and Williams (2003), also working in a Thompson Seedless vineyard at KAC, found a dramatic and positive correlation with $\mathrm{ET}_{\mathrm{c}}$ (on a scale from $0 \mathrm{ET}_{\mathrm{c}}$ to $1.6 \mathrm{ET}_{\mathrm{c}}$ ) and E. variabilis nymphal density and dry weight, as well as number of marked and recaptured adults.

Regulated deficit irrigation (RDI) (Chalmers et al. 1986) has seen a lot of interest in viticulture in California, Australia, and other semiarid viticultural re- 
gions. The concept of RDI is to reduce irrigation during critical points in the phenology of a cultivated woody plant, as opposed to a water deficit that is applied constantly throughout the growing season. The objectives of RDI include achieving a better balance between vegetative growth and production, and improvements in quality (Chaves et al. 2007). On wine grapes, RDI can be applied at different phenological stages, with varied effects on grape vigor, yield, and wine quality. Pre-berry set deficit is almost unheard of because of concerns about severe crop decline. Postberry set (early to mid-June) but preveraison (early to late July) deficit has resulted in a smaller canopy, smaller berry size, and higher concentration of anthocyanins and phenolics (Matthews and Anderson 1988) but in addition reduces yield (Coombe and McCarthy 2000). Post-veraison deficit tends to delay berry sugar accumulation, also may reduce berry weight, and can negatively affect accumulation of berry flavor compounds (Coombe and McCarthy 2000). Typically, RDI imposition does not begin until after berry set, and sometimes the initiation is based on a degree of vine water status (Prichard et al. 2004).

RDI also can be applied to leafhopper management. In California, Erythroneura spp. have two to three generations per year, depending on the region and weather: three and sometimes a partial fourth in the San Joaquin Valley, two and sometimes a partial third in coastal areas. The phenology of the grapevine and that of the leafhopper coincide such that maturation of the first generation tends to correspond to the late bloom period, and mating and oviposition of second generation eggs coincide with berry set. My hypothesis was that a mid-season water deficit, initiated at berry set and applied until veraison, should have a negative impact on the second generation of leafhoppers. With this in mind, I undertook a series of experiments to test the timing of RDI on population density of leafhoppers. The effects of these treatments on crop yield and quality are presented in another article.

\section{Materials and Methods}

I conducted one of the year 2000 experiments at the Aliso vineyard $\approx 10 \mathrm{~km}$ east of Firebaugh, Madera County, in the San Joaquin Valley, and the other experiments at the Frankel vineyard, $\approx 12 \mathrm{~km}$ east of Paso Robles, San Luis Obispo County, on the Central Coast. The Aliso vineyard was a 5-yr-old block of Cabernet Sauvignon, trained to a bilateral cordon with a single catch wire and spur pruned, with vine spacing $2.1 \mathrm{~m}$ within the row and $3.3 \mathrm{~m}$ between rows. The Frankel vineyards were 10-yr-old blocks of Cabernet Sauvignon, trained to a bilateral cordon vertical shoot positioned, and spur pruned, with vine spacing $1.5 \mathrm{~m}$ within the row and $3.0 \mathrm{~m}$ between rows. The Frankel (2000) vineyard was a small, isolated block of $\approx 1$ ha, whereas the site at Frankel (2002) was part of a larger block of $\approx 10$ ha. Soil type at Aliso consisted of Calhi loamy sand to El Peco Dinuba fine sandy loam. Soil type at Frankel (2000) was a San Ysidro loam with underlying clay subsoil, and at Frankel (2002) the soil type was classified as Arbuckle-Positas complex (coarse to fine sandy loam with underlying clay subsoil).

At each site, pesticides applied consisted of elemental sulfur and demethylation inhibitor fungicides for powdery mildew (Erysiphe necator Schwein); and at Aliso, cryolite (sodium hexafluoroaluminate) for omnivorous leafroller (Platynota stultana Walsingham). At Frankel (2000), imidacloprid was applied for leafhoppers on 18 August, which effectively ended the study for that season.

Each experiment was designed as a randomized complete block, with treatments replicated four times. Plots at the Aliso site were four rows wide by 190 vines long (plot size $\approx 0.5 \mathrm{ha}$ ). At Frankel (2000) plots were four rows wide by 18 vines long $\left(356 \mathrm{~m}^{2}\right)$, and at Frankel (2002) plots were four rows wide by eight vines long $\left(158 \mathrm{~m}^{2}\right)$. Adult leafhoppers are highly mobile, and it can be assumed that they were freely migrating among the plots in each study, i.e., they were able to choose which treatments to feed and oviposit in.

Treatments at each site consisted of one mid-season deficit irrigation compared with a control. The control was based on the grower standard, i.e., each grower's normal irrigation practices, assuming the grower would irrigate between $0.8-1.0 \mathrm{ET}_{\mathrm{c}}$ throughout the season, where $\mathrm{ET}_{\mathrm{c}}$ is the estimated amount of water evaporated from the field surface and transpired by the grape crop. Williams (2000) has shown that grape yield is maximized at $0.8 \mathrm{ET}_{\mathrm{c}}$. In this study, the standard irrigation practice of each grower was the control, and I did not attempt to manipulate this practice; again, I assumed that each grower would irrigate between 0.8 and $1.0 \mathrm{ET}_{\mathrm{c}}$. The final estimated $\mathrm{ET}_{\mathrm{c}}$ (i.e., where each control ended up on the 0.8-1.0 ET, continuum) is presented in the Results. For the deficit treatment, I attempted to reduce the amount of water applied to $<50 \%$ of the grower standard irrigation between berry set and veraison; the treatments hereafter are known as deficit irrigation and standard irrigation or control. At Aliso, the deficit was undertaken between 1 June and 20 July (Table 1). At Frankel (2000), a $50 \%$ of control deficit was initiated on 23 June, but because after 3 wk this deficit did not produce a difference in leaf water potential, the deficit was intensified to $25 \%$ of control for three more weeks, until 4 August. For the Frankel (2002) study, I compared a moderate deficit (reduction of the grower standard irrigation to about half of the control) to a severe deficit (reduction of the grower standard irrigation to about one quarter of the control) for the period 20 June-1 August, and treatments hereafter are known as moderate and severe deficits.

At each site, I regulated the deficit irrigations using in-line programmed controllers (Gilmour, Somerset, PA), and the amount of water applied was estimated by attaching a drip emitter to a collection container, which was monitored weekly. Again, I did not attempt to regulate the control; that was left up to each grower, assuming that each would irrigate between 80 and $100 \%$ of $\mathrm{ET}_{\mathrm{o}}$. To estimate the amount of water applied by each grower for the control treatment, and hence, 
Table 1. Estimated reference evapotranspiration $\left(\right.$ ET $\left._{\mathrm{o}}\right)$ and grape crop evapotranspiration $\left(\right.$ ET $\left._{\mathrm{c}}\right)$, and estimated water applied to the study plots in millimeters for the period of deficit, for control ("grower standard") and midseason deficits at the Firebaugh (Aliso 2000) and Paso Robles sites (Frankel 2000 and 2002)

\begin{tabular}{|c|c|c|c|c|c|}
\hline Site, yr, and deficit period & $\begin{array}{c}\mathrm{ET}_{\mathrm{o}} \\
(\mathrm{mm})\end{array}$ & $\begin{array}{r}\mathrm{ET}_{\mathrm{c}} \\
(\mathrm{mm})\end{array}$ & Control $(\mathrm{mm})$ & $\begin{array}{l}\text { Moderate deficit } \\
(\mathrm{mm})\end{array}$ & $\begin{array}{l}\text { Severe deficit } \\
(\mathrm{mm})\end{array}$ \\
\hline Aliso, Firebaugh (2000) & 351.0 & 307.3 & 274.4 & 116.1 & \\
\hline 1 June-20 July & & & $\left(0.89 \mathrm{ET}_{\mathrm{c}}\right)$ & $\left(0.38 \mathrm{ET}_{\mathrm{c}}\right)$ & \\
\hline Frankel, Paso Robles (2000) & 231.2 & 94.8 & 93.3 & 29.9 & \\
\hline 23 June-4 Aug. & & & $\left(0.98 \mathrm{ET}_{\mathrm{c}}\right)$ & $\left(0.32 \mathrm{ET}_{\mathrm{c}}\right)$ & \\
\hline Frankel, Paso Robles (2002) & 572.88 & 236.6 & 219.1 & 111.8 & 61.5 \\
\hline 19 June-1 Aug. & & & $\left(0.92 \mathrm{ET}_{\mathrm{c}}\right)$ & $\left(0.47 \mathrm{ET}_{\mathrm{c}}\right)$ & $\left(0.26 \mathrm{ET}_{\mathrm{c}}\right)$ \\
\hline
\end{tabular}

Estimated fraction of $\mathrm{ET}_{\mathrm{c}}$ is in parentheses below for each treatment at each study site and year.

the degree of deficit irrigation of the treatments, I estimated $\mathrm{ET}_{\mathrm{c}}$ by the formula $\mathrm{ET}_{\mathrm{c}}=\mathrm{k}_{\mathrm{c}} \times \mathrm{ET}_{\mathrm{o}}$, where $\mathrm{k}_{\mathrm{c}}$ is the crop coefficient and $\mathrm{ET}_{\mathrm{o}}$ is the reference evapotranspiration estimate, based on the water use of a managed grass crop. For the Aliso site, $I$ used the $k_{c}$ values published by Williams et al. (2003) and ET values from the CIMIS weather station in Firebaugh, and for the Frankel sites I used the $k_{c}$ values from

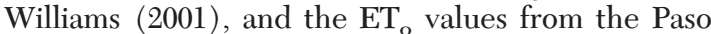
Robles Vintners and Growers Association weather station in Paso Robles. The estimated amount of water applied at each field site, treatment, and year, plus estimated $\mathrm{ET}_{\mathrm{c}}$ for period of deficit, are summarized in Table 1. Before the imposition of the deficit irrigation treatments, all vines in the study area were watered according to each grower's irrigation schedule. After the deficit, irrigation was set to $80 \%$ of the grower standard at Aliso, and to $100 \%$ of the grower standard at Frankel (2000 and 2002).

At each site and in each study year, we took weekly counts of leafhopper nymphal density (nymphs per leaf) on 20 leaves per plot, beginning 2 to $3 \mathrm{wk}$ before initiation of the deficit. In 2000, we took leaf water potential readings using a pressure bomb (PMS Instruments, Corvallis, OR), taking five readings per plot between the hours of 1100 and 1400 hours. Leaves selected for measurement were mature and in full sun. For each leaf, the petiole was cut with a razor blade, the entire leaf was placed into a plastic bag, and placed into the chamber within $30 \mathrm{~s}$. Williams and Araujo (2002) found that bagging after cutting the petiole resulted in lower readings than if the leaf were bagged before cutting ( $\approx 8 \%$ lower under deficit irrigation and $\approx 12 \%$ lower with full irrigation). In 2002, we measured net photosynthesis with an LI-6200 $\mathrm{CO}_{2}$ porometer (LI-COR, Lincoln, NE). Leaves selected for measurement were mature and in full sun. We sampled leafhopper eggs after the second generation of leafhoppers was completed, on 4 August at Aliso, and on 18 August at Frankel (2000), and counted on 20 halfleaves per plot. Eggs were scored as hatched, parasitized (by Anagrus spp. [Hymenoptera: Mymaridae]), or live.

Leafhopper density, leaf water potential and net photosynthesis were analyzed by repeated measures analysis of variance (ANOVA) (PROC GLM, SAS Institute 2001), with deficit intensity as the betweensubjects effects, and means separation by single de- gree of freedom orthogonal contrasts (SAS Institute 2001). Differences were considered statistically significant at $P<0.05$.

\section{Results}

Applied Water. At Aliso, the grower standard amounted to $\approx 0.89 \mathrm{ET}_{\mathrm{c}}$, and the deficit $\approx 42 \%$ of the grower standard between 1 June and 20 July (Table 1 ). The final estimate, then, of the Aliso deficit treatment was $0.38 \mathrm{ET}_{\mathrm{c}}$ during the deficit period. At Frankel (2000), the grower standard amounted to $\approx 0.98 \mathrm{ET}_{\mathrm{c}}$ and the deficit $\approx 31.5 \%$ of the grower standard from 23 June to 4 August (Table 1). Therefore, the estimated deficit at Frankel (2000) was 0.32 ET $_{\mathrm{c}}$ during the deficit period. At Frankel (2002), the grower standard amounted to $\approx 0.92 \mathrm{ET}_{\mathrm{c}}$, and between 19 June and 1 August the deficit from the grower standard was $51.0 \%$ for the moderate deficit treatment, and $28 \%$ for the severe deficit (Table 1). Therefore, the final estimated deficit was $0.47 \mathrm{ET}_{\mathrm{c}}$ for the moderate treatment and $0.26 \mathrm{ET}_{\mathrm{c}}$ for the severe treatment during the deficit period.

Vine Water Stress. As noted in Materials and Methods, leaves were bagged after cutting, so the readings presented in Figs. 1 and 2 can assumed to be $8-12 \%$ lower (more negative) than if bagged and then cut (Williams and Araujo 2002). At Aliso, a difference between treatments was seen almost immediately after water stress was initiated. In the deficit treatment, leaf water potential was lower by $9.7 \%$ for the $13-w k$ period between the initiation of the deficit and the end of the study ( $F=115.53$; $\mathrm{df}=1,44 ; P<0.0001$ ) (Fig. $1)$. Remember that at Aliso, after the intense deficit period, the deficit continued at 0.8 of standard irrigation. At Frankel (2000), water stress did not differ between treatments for the first $6 \mathrm{wk}$ after initiation of the deficit, but leaf water potential was lower by $3.7 \%$ in the deficit compared with control from 28 July to 25 August ( $F=5.62 ; \mathrm{df}=1,27 ; P=0.0251$ ) (Fig. 2).

At Frankel (2002), a reduction in net photosynthesis was seen almost immediately after initiation of the deficits; for the period of 20 June to 15 August the reduction was $18.8 \%$ in the deficit treatments compared with control $(F=24.21$; df $=1,42 ; P<0.0001)$ (Fig. 3). In addition, the severe deficit treatment was $13.1 \%$ lower than the moderate deficit during this period ( $F=17.50$; df $=1,42 ; P=0.0001$ ) (Fig. 3 ). 


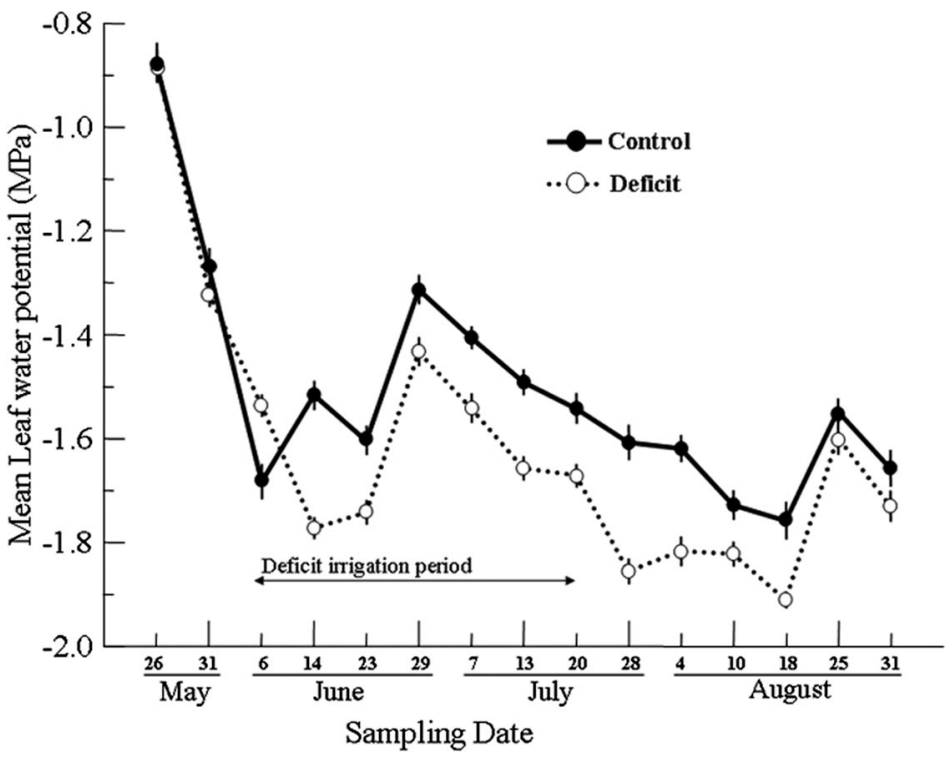

Fig. 1. Leaf water potential (megapascals), Aliso vineyard, 2000. Water stress in the deficit treatment increased by $9.7 \%$ overall $(F=115.53$; $\mathrm{df}=1,44 ; P<0.0001)$ between the period of deficit initiation and the end of the study.

Stomatal conductance was equivalent among all treatments beginning $2 \mathrm{wk}$ after cessation of the deficit irrigation.

Leafhopper Nymphal Density. The Aliso field site was dominated by E. elegantula, with E. variabilis, comprising $28.3,2.2$, and $2.1 \%$ of the nymphal population in generations one, two and three, respectively. At Frankel (2000 and 2002), all nymphal counts were E. elegantula.

Results from all three studies show a clear and negative effect of mid-season deficit on nymphal density. At Aliso, the deficit was induced $\approx 3$ wk before second generation leafhopper eclosion. Density in the second generation (14 June-28 July) peaked at $5.8 \pm$
0.6 nymphs per leaf under standard irrigation and at $2.3 \pm 0.3$ nymphs per leaf under the deficit treatment (a $60 \%$ difference), and at $12.5 \pm 1.5$ nymphs per leaf in the standard irrigation and $3.5 \pm 0.7$ nymphs per leaf in the deficit in the third generation (a 72\% decline) (28 July-31 August) (Fig. 4). Compared with the standard, deficit irrigation reduced second generation nymphal density by $52.0 \%(F=16.90 ; \mathrm{df}=1,602 ; P<$ $0.0001)$ and third generation by $61.7 \%(F=33.31 ; \mathrm{df}=$ 1, 603; $P<0.0001$ ) (Fig. 4). At Frankel (2000), the deficit was initiated $\approx 5 \mathrm{wk}$ before second generation eclosion. Second generation (21 July-18 August) density peaked at $11.1 \pm 1.2$ nymphs per leaf under standard irrigation and at $4.5 \pm 1.0$ under the deficit (a

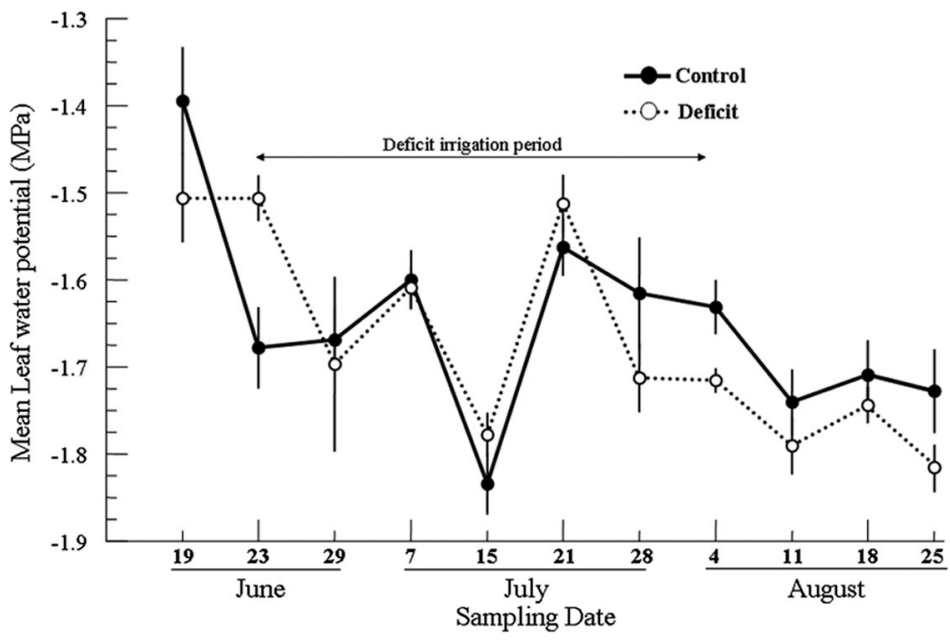

Fig. 2. Leaf water potential (megapascals), Frankel vineyard, Paso Robles, 2000. Water stress did not differ between treatments for the first $6 \mathrm{wk}$ after initiation of the deficit; however, water potential in the deficit treatment was $4 \%$ lower than the control from 28 July-25 August $(F=5.62 ; \mathrm{df}=1,27 ; P=0.0251)$. 


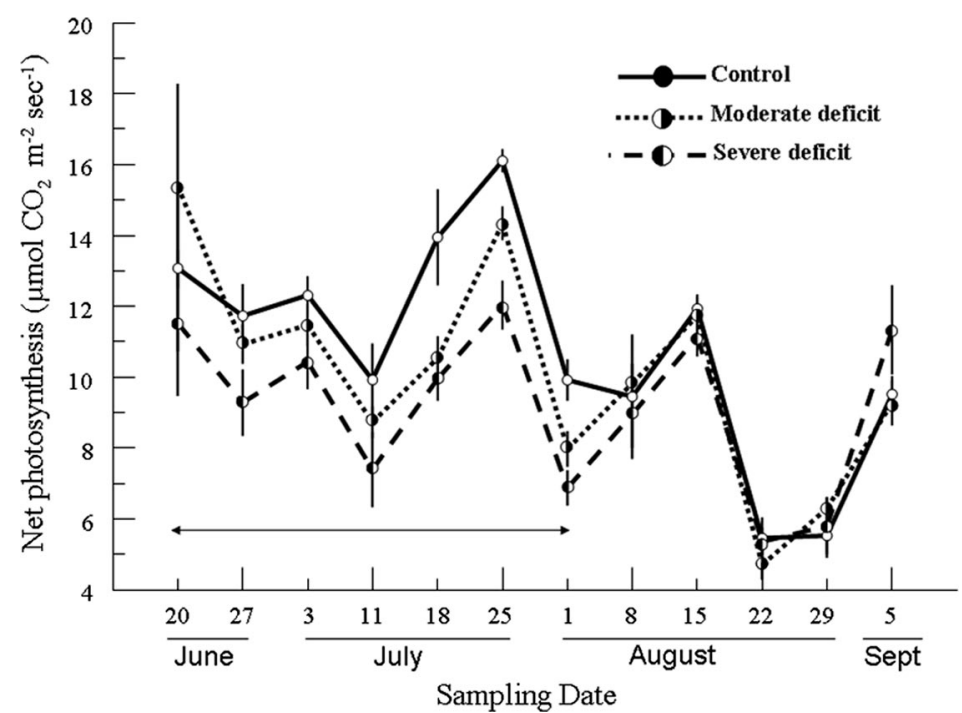

Fig. 3. Net photosynthesis (micromoles per meter squared per second) among deficit and control treatments, Frankel vineyard, Paso Robles, 2002. Photosynthesis was $18.8 \%$ lower in deficit compared with control from 20 June to 15 August $(F=$ $24.21 ; \mathrm{df}=1,42 ; P<0.0001)$, and it was $13.1 \%$ lower under the severe deficit compared with the moderate deficit $(F=17.50$; df $=1,42 ; P=0.0001)$.

59.4\% difference) (Fig. 5). Second generation density was lower by $51.3 \%$ under the deficit compared with the standard irrigation $(F=105.81$; $\mathrm{df}=1,155 ; P<$ 0.0001) (Fig. 5). At Frankel (2002), second generation (18 July-12 September) peak density in the standard irrigation was $3.2 \pm 0.5$ nymphs per leaf; for the moderate deficit, it was $1.6 \pm 0.2$ (a $50 \%$ decline); and for the severe deficit, it was $1.0 \pm 0.2$. The deficit treatments had a significant impact on second generation leafhoppers (contrast: $F=86.94$; $\mathrm{df}=1,234 ; P<$ $0.0001)$, lowering density by $39.8 \%$ compared with the standard irrigation. In addition, second generation leafhopper density in the severe deficit was lower by 4.5\% compared with the moderate deficit (contrast: $F=16.58 ; \mathrm{df}=1,234 ; P<0.0001$ ) (Fig. 6).

Leafhopper Egg Density. At Aliso, total second generation egg density was reduced by $54 \%$ under deficit $(F=9.70 ; \mathrm{df}=1,135 ; P=0.002)$ and hatched eggs by $\approx 44 \%(F=6.64 ; \mathrm{df}=1,135 ; P=0.011)$ (Table 2). The rate of parasitism was $\approx 36 \%$ under control and $40 \%$ under deficit, not a statistically significant difference (Table 2). At Frankel (2000), second generation total

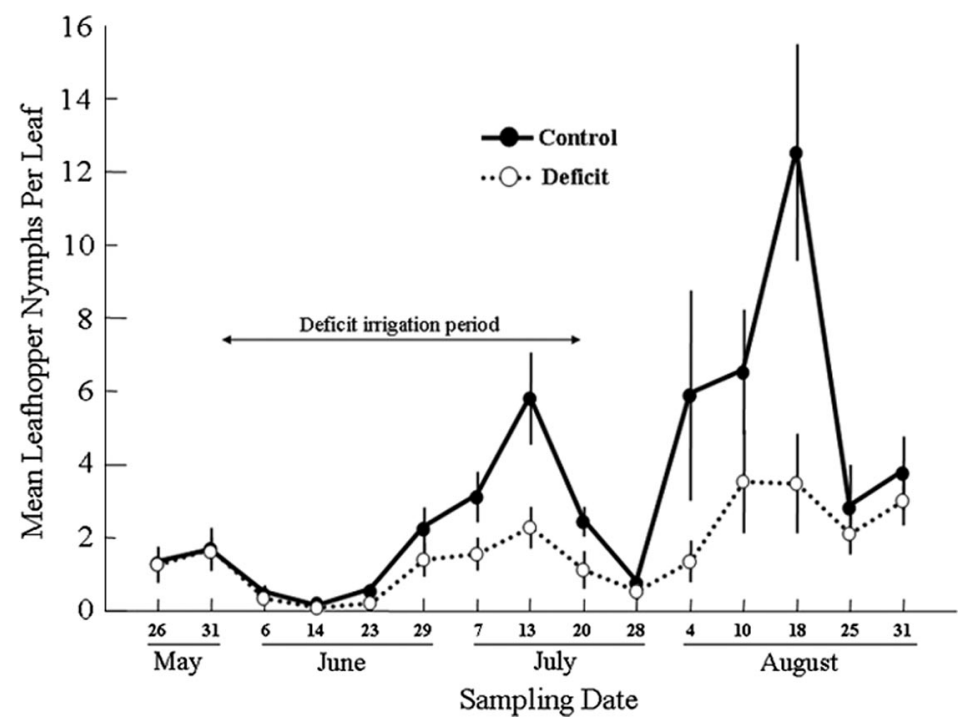

Fig. 4. Seasonal mean leafhopper density (nymphs per leaf \pm SE), Aliso vineyard, Firebaugh, 2000. Deficit irrigation reduced second generation density by $52 \%(F=16.90 ; \mathrm{df}=1,602 ; P<0.0001)$ and third generation by $61.7 \%(F=33.31$; df $=1,603 ; P<0.0001)$ compared with control. 


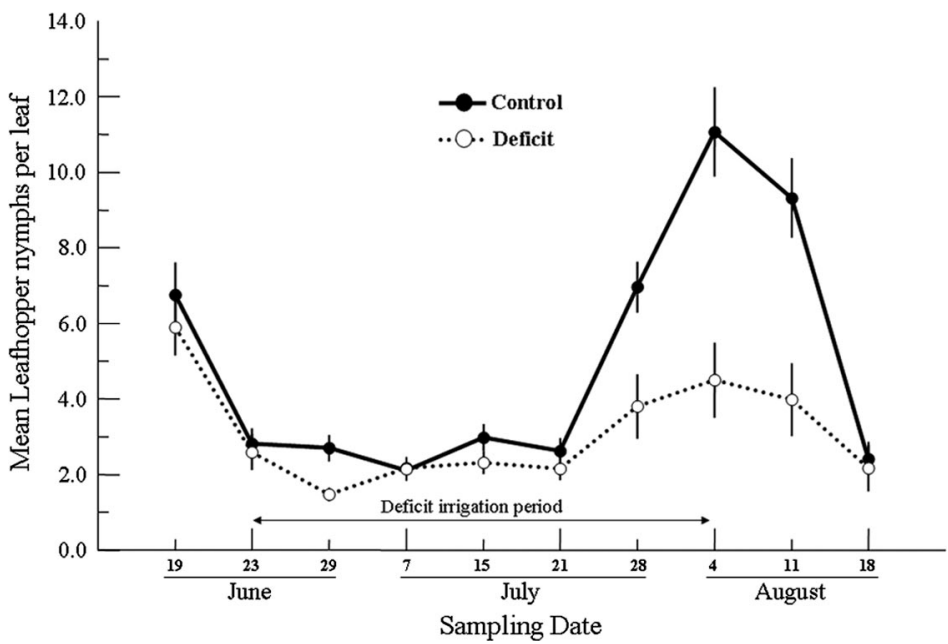

Fig. 5. Seasonal mean leafhopper density (nymphs per leaf \pm SE), Frankel vineyard, Paso Robles, 2000. Deficit irrigation lowered second generation density by $51.3 \%(F=105.81$;f $=1,155 ; P<0.0001)$ compared with control.

egg density was $29.9 \%$ lower under deficit $(F=25.86$; df $=1,155 ; P<0.0001)$, and hatched eggs were $29.7 \%$ lower $(F=6.86$; df $=1,155 ; P=0.01)$ (Table 2$)$. Parasitism was significantly lower under deficit $(10.7 \%)$ compared with control $(19.6 \%) \quad(F=5.62$; $\mathrm{df}=1,132 ; P=0.019)$ (Table 2 ).

\section{Discussion}

This study confirms previous findings (Trichilo et al. 1990; Daane and Williams 2003) that Erythroneura spp. density is lower on water stressed vines. Moreover, the current study shows that season-wide irrigation deficit is not necessary for a reduction in leafhopper density. The results from Frankel (2002) also support the re- lationship between intensity of deficit and degree of leafhopper density reduction found in the studies of Trichilo et al. (1990) and Daane and Williams (2003). Also, at one site, Aliso, the difference in nymphal density between standard and mid-season deficit treatments carried over into the third generation, well beyond the initial six-week deficit period. Most likely this is because there the irrigation rate was maintained at 0.80 of standard irrigation after the initial intense deficit period.

Variability among field sites in leafhopper density with irrigation manipulation is bound to depend on soil type, which was something also noted by Trichilo et al. (1990). In the current studies, although both the Aliso (coarser soil texture) and Frankel (finer soil

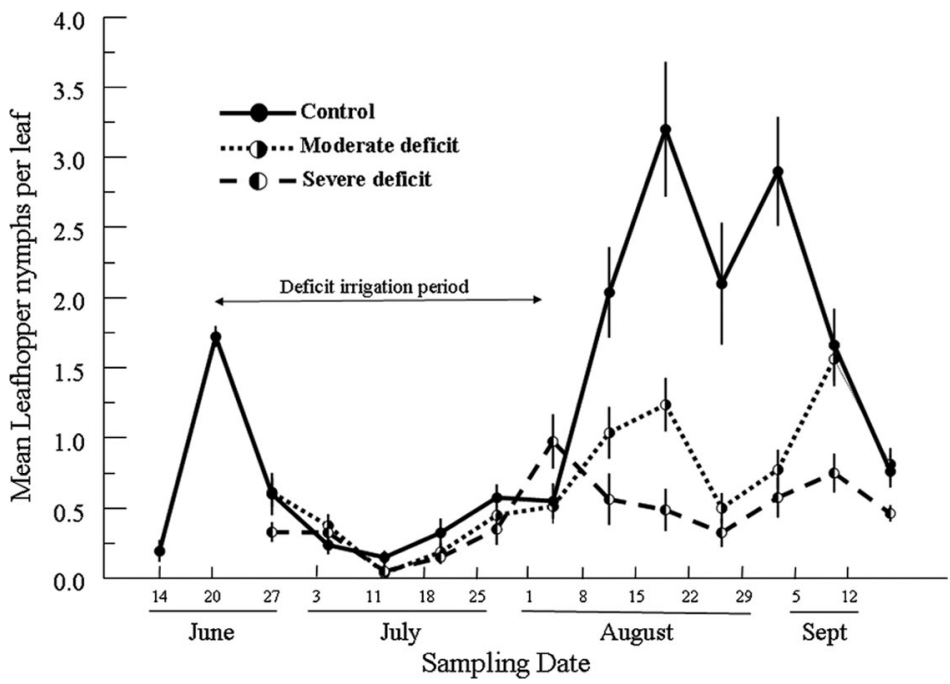

Fig. 6. Seasonal mean leafhopper density (nymphs per leaf \pm SE), Frankel vineyard, Paso Robles, 2002. second generation density was reduced by $39.8 \%$ in the deficit treatments compared with control $(F=86.94$; df $=1,234 ; P<0.0001)$ by $4.5 \%$ when moderate deficit was compared with severe deficit $(F=16.58$; $\mathrm{df}=1,234 ; P<0.05)$. 
Table 2. Second generation leafhopper egg density and percentage of parasitism by Anagrus spp., Aliso and Frankel vineyards, 2000

\begin{tabular}{lccc}
\hline \hline \multicolumn{1}{c}{ Vineyard } & Mean total eggs/leaf & Mean hatched eggs/leaf & Mean \% parasitism \\
\hline Aliso, Firebaugh & $6.45 \pm 0.78$ & $2.98 \pm 0.39$ & $0.36 \pm 0.05$ \\
$\quad$ Control & $2.93 \pm 0.39$ & $1.67 \pm 0.32$ & $0.40 \pm 0.08$ \\
Deficit & $F=9.70 ; \mathrm{df}=1,135 ; P=0.002$ & $F=6.64 ; \mathrm{df}=1,135 ; P=0.011$ & $F=0.54 ; \mathrm{df}=1,91 ; P=0.462$ \\
& & & \\
Frankel, Paso Robles & $16.15 \pm 1.38$ & $9.83 \pm 0.87$ & $0.20 \pm 0.03$ \\
Control & $11.33 \pm 1.68$ & $6.90 \pm 0.85$ & $0.11 \pm 0.02$ \\
Deficit & $F=25.86 ; \mathrm{df}=1,155 ; P<0.0001$ & $F=6.86 ; \mathrm{df}=1,155 ; P=0.01$ & $F=5.62 ; \mathrm{df}=1,132 ; P=0.019$ \\
& & &
\end{tabular}

texture) sites had lower leafhopper densities with mid-season irrigation deficits, the Frankel site was more buffered with respect to soil water. This can be seen in the greater lag time at Frankel versus Aliso between water deficit initiation and the time at which pressure bomb readings or leafhopper nymphal counts began to differ among treatments.

Several hypotheses have been put forth to explain the mechanism for the lowered density of leafhopper nymphs on water stressed plants, including altered microclimate, oviposition, egg mortality, and nymphal mortality. Trichilo et al. (1990) discussed the possibility that fully watered vines have a cooler microclimate, which could lead to a preference by leafhoppers; however, this hypothesis has not been tested previously nor was it in the current study. Working with $E$. fabae, Hoffman and Hogg (1992) found a lower rate of oviposition on water stressed alfalfa, which they attributed to a higher rate of adult leafhopper emigration. Daane and Williams (2003), in a field cage study, found oviposition of $E$. variabilis $50 \%$ lower on vines irrigated season-wide at $1.2 \mathrm{ET}_{\mathrm{c}}$ compared with 0.6 $\mathrm{ET}_{\mathrm{c}}$. However, they found that female nymphs that fed on water-stressed versus well-watered vines did not differ in fecundity as adults. Therefore, they suggested that lower oviposition, not lower fecundity, is a leafhopper response to vine water stress. This, coupled with the knowledge that adult leafhoppers are highly mobile and freely able to move among plots, indicates that at Aliso and Frankel (2000), leafhopper oviposition was reduced because of an aversion on the part of adult female leafhoppers to the water stressed vines.

Daane and Williams (2003) discuss the possible mechanisms involved in lowered leafhopper numbers on grapevines receiving less water, including poor food quality for adults, and an aversion to oviposition due to a change in leaf structure. In addition, there may be a degree of leaf water potential below which female Erythroneura spp. will not oviposit. Egg mortality differed between $12-15$ percentage points between well-watered and water-stressed alfalfa in a study on E. fabae (Hoffman et al. 1990). However, in the current study, the evidence that a difference in egg mortality between well-watered and deficit vines played a role is mixed, based on a comparison between treatments in the density of hatched and total eggs. At Aliso, in the standard irrigation, the density of hatched eggs was $54 \%$ lower than total eggs, and in the deficit the difference was $43 \%$, suggesting that abiotic egg mortality (due to water stress) at least partially accounted for the 11 percentage point difference. However, at Frankel (2000), there was exactly the same reduction in hatched eggs compared with total eggs (39\%) in both standard irrigation and deficit treatments, indicating that abiotic mortality due to drought stress was not a factor. Therefore, egg mortality may be a contributing factor to lower leafhopper density water-stressed grapevines, but it cannot be a general explanation.

Another possible mechanism is that leafhopper nymphal mortality is higher on water stressed vines. To my knowledge, no published study exists which has analyzed this. In the present studies, the percent difference between treatments in peak nymphal density at Aliso (60\%) and Frankel (2000) (59\%) (Figs. 1 and 2) is greater than the percentage of difference in hatched eggs (Aliso, 44\%; Frankel [2000], 29\%) (Tables 1 and 2). Because parasitism did not differ between treatments, this suggests that the unexplained mortality is due to higher nymphal mortality in the deficit treatments. It is possible that nymphal mortality is greater on the deficit vines because leaf cuticle is thicker, making nymphal stylet penetration more difficult. It is well known that leaf cuticle thickness can increase in response to water deficit (Levitt 1972); however, this tends to be a consequence of long-term stress. Still, no one has analyzed the time frame in which grape leaf cuticle thickens in response to water stress, nor the degree to which this might occur. Another possibility is that low water potential (low free energy of water) makes it more difficult for leafhoppers to extract the contents of mesophyll cells, something suggested by Connor (1988), working with adult tingids. Again, no one has looked at this experimentally involving leafhoppers on grape.

\section{Acknowledgments}

Thanks to students Bryce Gross, Jo Harper, and Catherine Albers for field and laboratory assistance, and also to Martin Britz, Kip Green, and Gurmit Singh (Britz Farming, Inc.) for providing the field site for the study. I am very grateful to the California Agricultural Technology Institute at California State University, Fresno, and the California Agricultural Research Initiative for partial funding of these studies. 


\section{References Cited}

California Department of Pesticide Regulation. 2000. Summary of pesticide use report data, 1999, indexed by commodity. California Environmental Protection Agency, Department of Pesticide Regulation.

Chalmers, D. J., G. Burge, P. H. Jerie, and P. D. Mitchell. 1986. The mechanism of regulation of Bartlett pear fruit and vegetative growth by irrigation withholding and regulated deficit irrigation. J. Am. Soc. Hortic. Sci. 111: $904-$ 907.

Chaves, M. M., T. P. Santos, C. R. Souza, M. F. Ortuño, M. L. Rodrigues, C. M. Lopes, J. P. Maroco, and J. S. Pereira. 2007. Deficit irrigation in grapevine improves water-use efficiency while controlling vigour and production quality. Ann. Appl. Biol. 150: 237-252.

Connor, E. F. 1988. Plant water deficits and insect responses: the preference of Corythucha arcuata (Heteroptera: Tingidae) for the foliage of white oak, Quercus alba. Ecol. Entomol. 13: 375-381.

Coombe, B. G., and M. G. McCarthy. 2000. Dynamics of grape berry growth and physiology of ripening. Aust. J. Grape Wine Res. 6: 131-135.

Daane, K. M., and L. E. Williams. 2003. Manipulating vineyard irrigation amounts to reduce insect pest damage. Ecol. Appl. 13: 1650-1666.

Flint, H. M., S. E. Naranjo, J. E. Leggett, and T. J. Henneberry. 1996. Cotton water stress, arthropod dynamics, and management of Bemisia tabaci (Homoptera: Aleyrodidae). J. Econ. Entomol. 89: 1288-1300.

Hoffman, G. D., D. B. Hogg, and G. M. Boush. 1990. The effect of plant-water stress on potato leafhopper, Empoasca fabae, egg developmental period and mortality. Entomol. Exp. Appl. 57: 165-175.

Hoffman, G. D., and D. B. Hogg. 1992. Effect of alfalfa water stress on potato leafhopper (Homoptera: Cicadellidae) plant preference and oviposition rate. Ann. Entomol. Soc. Am. 85: 506-516.

Levitt, J. 1972. Responses of plants to environmental stress. Academic, New York.

Matthews, M. A., and M. M. Anderson. 1988. Fruit ripening in Vitis vinifera L.: responses to seasonal water deficits. Am. J. Enol. Vitic. 39: 313-320.

Prichard, T., B. Hanson, L. Schwankl, P. Verdegaal, and R. Smith. 2004. Deficit irrigation of quality winegrapes using micro-irrigation techniques. University of California Cooperative Extension, Department of Land, Air and Water Resources, University of California, Davis, CA

SAS Institute. 2001. SAS/ STAT user's guide, release 8.02 ed SAS Institute, Cary, NC

Trichilo, P. J., L. T. Wilson, and D. W. Grimes. 1990. Influence of irrigation management on the abundance of leafhoppers (Homoptera: Cicadellidae) on grapes. Environ. Entomol. 19: 1803-1809.

Williams, L. E. 2000. Grapevine water relations. Pages 121126 In L. P. Christensen [ed.], Raisin production manual. University of California, Division of Agriculture and Natural Resources, Publication 3393, Oakland, CA.

Williams, L. E. 2001. Irrigation of winegrapes in California. Pract. Winery Vineyard 23: 42-55.

Williams, L. E., and F. J. Araujo. 2002. Correlations among predawn leaf, midday leaf, and midday stem water potential and their correlations with other measures of soil and plant water status in Vitis vinifera. J. Am. Soc. Hortic. Sci. 127: 448-454

Williams, L. E., C. J. Phene, D. W. Grimes, and T. J. Trout. 2003. Water use of mature Thompson Seedless grapevines in California. Irrigat. Sci. 22: 11-18.

Received 25 April 2007; accepted 14 February 2008 